\title{
Sensitivity evaluation in two commonly occurring freshwater fishes after intoxication with cadmium
}

\author{
Diwakar Ram Tripathi \\ (Department of Zoology, A. N. D. Kisan P.G. College, Babhnan, Gonda- 271 313, U. P., India) \\ Email-ID: diwakarram681@gmail.com
}

\begin{abstract}
The present observations were based on effects of cadmium on two commonly occurring freshwater fish, Channa punctatus (Bloch.) and Mystus tengara (Hamilton). The three different concentrations of cadmium chloride as $250 \mu \mathrm{g} / \mathrm{L}, 500 \mu \mathrm{g} / \mathrm{L}, 750 \mu \mathrm{g} / \mathrm{L}$ and $1000 \mu \mathrm{g} / \mathrm{L}$, were used in the present study. After intoxication the mortality rate, respiratory stress, weight change in liver and kidney for the same were observed. The present observation reveal that as the concentrations of cadmium chloride increases the respiratory stress and mortality rate also increases, but the rate of increase of these parameters is higher in Mystus tengara than Channa punctatus. It has been noticed that as the dose of cadmium chloride increases the weight of liver and kidney in these two fish species decreases rapidly. Whereas the weight declining rate of these organs is higher in Mystus tengara than Channa punctatsus. Thus, Mystus tengara was found to be more sensitive than Channa punctatus to the cadmium.
\end{abstract}

Keywords: Cadmium chloride, dose, fish, respiratory stress, toxicity.

\section{Introduction}

Aquatic pollution in now a subject of considerable interest and concern among scientists, the pollution of aquatic ecosystem by heavy metals received worldwide attention ever since the discovery of mercury as the cause of Minimata disease in Japan in 1950's which caused neurological disorders and heavy mortality. The fishes are not only able to accumulate but also to retain heavy metals present in their natural habitat. Studies have shown that exposure of fish to heavy metals leads to number of disturbed physiological processes. At fairly large concentrations, these heavy metals manifest their toxic effects on fish life, ultimately causing fish-kill. When fishes are exposed to heavy metals dissolved in water, the gills function as the major route for the uptake of these compounds. They are the organs not only involved in respiration and osmoregulation but also in nitrogen excretion and regulation of acid-base balance. Following uptake by the fish gill, further transport of the metals to other tissues is through the circulatory system.

The heavy metals are discharged through industrial effluents into freshwater resources. Amongst all cadmium toxicity in animals is well studied. It is one of the non-essential heavy metal known for its non corrosive nature and is widely used in paints, dyes, cement and phosphate fertilizers (Jarrup, 2003 and Reddy, 2012). Industrial discharges and mining activities are two major sources of cadmium pollution in water bodies. Cadmium as a water pollutant can alter the dynamics of aquatic ecosystem (Shukla et al., 2013). Cadmium is causing constant decline in global fish stock. It is extremely toxic and provokes adverse effects on the biota in general and particularly in fishes (Wright and Welbourn, 1994). There is a steady increase in the concentration of the cadmium in all habitats owing to mining, electroplating, paints, dyes and battery making industries (Forstner and Prosi, 1979). The release is rapid with the rapidly growing technology and heavy metal application in these industries. It is known to be highly toxic even in small concentrations (Scott and Slowman, 2004; Hatinik et al., 2005; Kesharwani et al., 2009 and Srianga et al., 2010). Although various literatures are available on toxicity of cadmium in different animals but limited studies have been done on the sensitivity of cadmium in different species of freshwater fish. The aim of present study was to evaluate the sensitivity in two different species of commonly occurring freshwater fish during cadmium toxicity. The sensitivity was measured in terms of respiratory stress, mortality rate and weight alterations in different vital organs like liver and kidney, which are the common organs involved in cadmium metabolism.

\section{Materials and Methods}

In the present study, two freshwater fish, Mystus tengara (Hamilton) and Channa punctatus (Bloch.) were selected as test fish because this species is hardy, readily available, easy to handle, can be held in healthy conditions for long period, and form an important species in many water resources.

Live specimens of adult freshwater fish, Mystus tengara and Channa punctatus (both of the sexes, body weight $80-100 \mathrm{gm}$ and length about $6.5-7.0 \mathrm{~cm}$ ) were procured locally. The fish were inspected for external signs of injury and diseases. Those, which showed such symptoms, were discarded and only the healthy ones were selected for experiments. These fish were acclimatized to the laboratory conditions (under natural 
photoperiod 12.12-12.38 and temperature $27.4 \pm 1.8^{\circ} \mathrm{C}$ ) for 15 days in plastic pools. Each pool contained $500 \mathrm{~L}$ of dechlorinated tap water.

The physicochemical characteristics of the tap water have been shown in Table 1. During acclimatization the both the species fish were fed daily with wheat flour pellets, commercial food pallets and dried shrimp powder, 2-3 times per day. Water was renewed daily after cleaning the fecal matter and leftover food. All care was taken to avoid giving stress to the fish. The fish were not fed 24 hour before and during the experimental period so that excretory substances may not influence the toxicity of test solutions. The mortality rate during acclimatization was less than four percent.

Table 1: Physicochemical characteristics of tap water used during test period

\begin{tabular}{|l|r|}
\hline Parameters & Mean \pm S.E. \\
\hline $\mathrm{pH}$ & $7.12 \pm 0.03$ \\
\hline Temperature $\left({ }^{\circ} \mathrm{C}\right)$ & $27.40 \pm 1.80$ \\
\hline Photoperiod (hours) & $12.12-12.38$ \\
\hline Dissolved oxygen $(\mathrm{mg} / \mathrm{L})$ & $7.78 \pm 0.30$ \\
\hline Hardness $(\mathrm{mg} / \mathrm{L})$ as $\mathrm{CaCO}$ & $169.32 \pm 5.40$ \\
\hline Electrical conductivity $(\mu \mathrm{mho} / \mathrm{cm})$ & $304.15 \pm 65.42$ \\
\hline
\end{tabular}

Acute cadmium toxicity tests were performed on both the specimens of fish. The cadmium chloride concentrations for both of the fish species- $250 \mu \mathrm{g} / \mathrm{L}, 500 \mu \mathrm{g} / \mathrm{L}, 750 \mu \mathrm{g} / \mathrm{L}$ and $1000 \mu \mathrm{g} / \mathrm{L}$, were chosen for the experiment on the basis of $\mathrm{LC}_{50}$ values as reported in different species of fish (Finney, 1971). The fishes were exposed to the above concentrations separately for five days in the aquaria of $40 \mathrm{~L}$ capacity. Five replicates each containing ten fish (kept in glass aquarium containing 40L of the test solution) were subjected to each concentration of the cadmium chloride $(250 \mu \mathrm{g} / \mathrm{L}, 500 \mu \mathrm{g} / \mathrm{L}, 750 \mu \mathrm{g} / \mathrm{L}$ and $1000 \mu \mathrm{g} / \mathrm{L})$ for the test. The cadmium chloride was dissolved in distilled water and then the desired volume of the solution was mixed in tap water to obtain the above mentioned concentration. For this heavy metal, a control group with five replicate (each containing $10 \mathrm{fish}$ ) kept in 40L tap water was also run. The solutions of all the aquaria (control and experimental) were renewed daily. Precautions were taken to remove the dead fish immediately because dead fish deplete dissolved oxygen which greatly affects toxicity data (Schreck and Brouha, 1975). Death in fish was confirmed when the movement of the operculum was stopped and the fish failed to respond when gently prodded at the caudal peduncle. Assays were terminated and results discarded if control mortality exceeds $10 \%$ at any time. The concentration of cadmium chloride and their degradation products were not measured during the course of bioassay as the facilities for it are not available.

The rate of mortality and respiratory stress were observed daily in these aquaria. At the end of the exposure periods (at different concentrations of cadmium chloride) the weight of liver and kidney in these sacrificed fishes of both species were taken. The above parameters were also compared with controlled groups. All the experiments were performed at room temperature.

\section{Results}

In the controlled group, all the fishes were survived during the experiment. The mortality rates in the exposed fishes were observed in both the species. The rate of mortality was almost similar at the lowest doses. However, a significant difference was noticed at the higher concentrations of cadmium chloride in these two species of fishes (Table 2).

The respiratory stress in Mystus tengara was found to be more than the species Channa punctatus, as it was observed that the rate of opening and closing of operculum (i.e., opercular beats) was more in the former species. It was also observed that Channa. punctatus was moving frequently upwardly at the surface water, presumably to get rid of cadmium poisoning (Table 3 ).

In the experimental fishes the weight of liver and kidney after 5 days of exposure with cadmium chloride, decreases progressively and when these data were compared with the controlled groups, it was observed that there is a significant reduction in weight at the higher concentrations of cadmium (Table 4 and $5)$.

Table 2: Mortality rate of fish, Mystus tengara and Channa punctatus after 120 hours of exposure with $\mathrm{CdCl}_{2}$.

\begin{tabular}{|c|c|c|}
\hline $\begin{array}{c}\text { Dose of CdCl } \\
(\boldsymbol{\mu} \mathbf{g} / \mathbf{L})\end{array}$ & Percent mortality in Mystus tengara & Percent mortality in Channa Punctatus \\
\hline 250 & $10 \%$ & $10 \%$ \\
\hline 500 & $40 \%$ & $20 \%$ \\
\hline 750 & $63 \%$ & $56 \%$ \\
\hline 1000 & $95 \%$ & $60 \%$ \\
\hline Control & $01 \%$ & Nil \\
\hline
\end{tabular}


Table 3: Respiratory stress (in terms of opercular beats/minute) after 120 hours of exposure with $\mathrm{CdCl}_{2}$.

\begin{tabular}{|c|c|c|}
\hline $\begin{array}{c}\text { Dose of } \mathbf{C d C l} \\
(\boldsymbol{\mu} \mathbf{g} / \mathbf{L})\end{array}$ & Opercular beats/minute in Mystus tengara & Opercular beats/minute in Channa Punctatus \\
\hline 250 & 35 & 32 \\
\hline 500 & 60 & 55 \\
\hline 750 & 71 & 68 \\
\hline 1000 & 85 & 80 \\
\hline Control & 27 & 25 \\
\hline
\end{tabular}

Table 4: Weight of Liver in response to cadmium toxicity for 120 hours.

\begin{tabular}{|c|c|c|}
\hline \multirow{2}{*}{$\begin{array}{c}\text { Dose of } \mathbf{C d C l}_{\mathbf{2}}(\boldsymbol{\mu} \mathbf{g} / \mathbf{L}) \\
n\end{array}$} & \multicolumn{2}{|c|}{ Weight of Liver (in grams) } \\
\cline { 2 - 3 } & & Channa punctatus \\
\hline 250 & 1.43 & 1.29 \\
\hline 500 & 1.40 & 1.27 \\
\hline 750 & 1.36 & 1.24 \\
\hline 1000 & 1.31 & 1.21 \\
\hline Control & 1.46 & 1.31 \\
\hline
\end{tabular}

Table 5: Weight of Kidney in response to cadmium toxicity for 120 hours.

\begin{tabular}{|c|c|c|}
\hline \multirow{2}{*}{\begin{tabular}{c} 
Dose of $\mathbf{C d C l}_{\mathbf{2}}(\boldsymbol{\mu g} / \mathbf{L})$ \\
\cline { 2 - 3 }
\end{tabular}} & \multicolumn{2}{|c|}{ Weight of Kidney (in grams) } \\
\hline 250 & 0.95 & 0.91 \\
\hline 500 & 0.89 & 0.86 \\
\hline 750 & 0.86 & 0.83 \\
\hline 1000 & 0.81 & 0.79 \\
\hline Control & 1.01 & 0.95 \\
\hline
\end{tabular}

\section{Discussions}

The controlled fishes of both the species were kept in glass aquaria tend to move together and often come to the surface to gulp air. At the other times, they either rest at the bottom or swim along sides of aquaria. The behavioural changes have been noticed in the exposed fishes of both the species. Fishes come to the surface of water much more frequently for the purpose of breathing air through their accessory respiratory organ. Moreover, exposed fishes exhibit increased opercular movement, slimy body and finally became sluggish. Also, they exhibit the curling of spines and abnormal (vertical) swimming movements including loss of equilibrium.

The dose response relationships as observed in these fishes demonstrate that Mystus tengara was more responsive than Channa punctatus to the cadmium poisoning. So, these findings indicate that the fish species Mystus tengara was more sensitive to the cadmium toxicity than the Channa punctatus. A similar result has also been reported by Sobha et al., 2007 and Shuhaini et al., 2010.

After reaching an animal's body, cadmium is transported in the body by red blood cells and large protein molecules. In fishes, cadmium has been reported to accumulate and cause serious damage to various tissues and organs (Hilmy et al., 1985; Rani, 2000; Bervoets et al., 2001; Rashed, 2001; Szebedinszky et al., 2001; Rangsayatorn et al., 2004; Wangsongsak et al., 2007; Oner et al., 2008; Ahmad et al., 2011). Thus, it is expected that the exposure to cadmium might have affected these vital organs (gills, liver and kidney), due to which the opercular beats increased and a significant reduction in weight at the higher concentrations have been observed.

The behavioural changes have been observed in the treated fishes as expressed by restlessness, surfacing, increased opercular beats, slimy body, sluggishness and loss of balance. Restlessness, surfacing, increased opercular beats and loss of balance has been reported in the fish Labeo rohita treated with an organophosphate insecticide dimethyl-parathion (Bengari et al., 1984). Choudhuri et al. (1984) and Singh et al. (1997) have reported thick coating mucous, inability to maintain axial balance and blanching of the skin in formothion and propoxur exposed Heteropneustes fossilis. The report of Mishra et al. (2005) in terms of acute toxicity and behavioural anomalies of a freshwater catfish, Heteropneustes fossilis to an organophosphate insecticide methyl-parathion favours the present study. The findings of Sobha et al. (2007) also supports the present observations in which it is mentioned that due to complete loss equilibrium fishes turned up and down side.

\section{Conclusion}

It is concluded from this study that the dose response relationships as observed in these fishes confirmed that Mystus tengara was more responsive than Channa punctatus to the cadmium poisoning. It is 
believed that the cadmium exposure might have influenced these vital organs like gills, liver and kidney etc. and caused such behavioural responses.

\section{Acknowledgements}

The author is thankful to Dr. K. K. Shukla (Ex. JRF), Indian Institute of Toxicology Research, Lucknow (U.P.), Mr. R. V. Prasad, Assistant Professor of Chemistry, A. N. D. Kisan P. G. College, Babhnan, Gonda (U.P.) and Dr. Diwakar Mishra, Assistant Professor of Zoology, Government Girls' P. G. College, Ghazipur (U.P.) for their heartily cooperation and suggestion for this study.

\section{References}

[1]. B. Ahmad, T. A. Quereshi, S. Manohar, P. Kaur, and K. Khaliq, Effect of cadmium chloride on the histoarchitecture in liver and kidney of a freshwater catfish, Clarias batrachus, International Journal of Environmental Science, 02, 2011, 531-536.

[2]. K.V. Bengari, K.M. Shivraj, and H.S. Patil, Toxicity of dimethyl-parathion to freshwater fish Labeo rohita and oxygen uptake rate of exposed fish, Environment and Ecology, 02, 1984, 01-04.

[3]. L. Bervoets, R. Blust, and R. Verheyen, Accumulation of metals in the tissues of three spined stickleback (Gasterosteus aculeatus) from natural fresh waters, Ecotoxicology and Environmental Safety, 48, 2001, 117-127.

[4]. D. K. Choudhuri, A. K. Sandhu, and P. K. Mukhopadhyay, Toxicity of two organophosphorus insecticides malathion and phosphamidon to the fish Channa striatus. Environment and Ecology, 02, 1984, 143-147.

[5]. D. J. Finney, Probit Analysis, Cambridge University Press, London, 1971.

[6]. U. Forstner, and F. Prosi, Heavy metal pollution in freshwater ecosystem, in biological aspects of freshwater pollution. In. O. Ravera (ed.), Pergmon Press, Oxford, 1979, 129-161.

[7]. J. Hatinik, D. B. Brock, and R. Blust,.The toxicokinetics of cadmium in carp under normoxic and hypoxic condition, Aquatic Toxicology, 75, 2005, 01-15.

[8]. A. M. Hilmy, M. B. Shabana, and A.Y. Daabees, Bioaccumulation of cadmium: Toxicity in Mugil cephalus. Comparative Biochemistry and Physiology, 81, 1985, 139-144.

[9]. L. Jarrup, Hazards of heavy metal contamination, Brazillian Medical Bulletin, 68, 2003, 167-182.

[10]. D. Kesharwani, H. C. Lodhi, K. J. Tiwari, S. Shukla, and U. P. Sharma, Cadmium toxicity in freshwater catfish Heteropneustes fossilis (B1.), Asian Journal of Experimental Science, 23, 2009, 149-150.

[11]. D. Mishra, S. K. Srivastav, and A. K. Srivastav, Acute toxicity and behavioural anomalies of a freshwater catfish, Heteropneustes fossilis to an organophosphate insecticide methyl-parathion, Pollution Research, 24, 2005, 307-310.

[12]. M. Oner, G. Atli, and M. Canli, Changes in serum biochemical parameters of freshwater fish Oreochromis niloticus following prolonged metal (Ag, Cd, Cr, Cu, Zn) exposures, Environmental Toxicology and Chemistry, 27, 2008, 360-366.

[13]. J. S. Reddy, Cadmium: effect on histo-biomarkers and melano- Macrophage centers in liver and kidney of Cyprinus carpio, World Journal of Fishery and Marine Science, 04, 2012, 179-184.

[14]. N. Rangsayatorn, M. Kruatrachue, P. Pokethitiyook, E. S. Upatham, G. R. Lanza, and S. Singhakaew, Ultrastructural changes in various organs of the fish Puntius gonionotus fed cadmium enriched cyanobacteria. Environmental Toxicology, 19, 2004, 585593.

[15]. A. U. Rani, Cadmium-induced bioaccumulation in the selected tissues of a freshwater teleost, Oreochromis mossambicus (tilapia), Annals of The New Yark Academy of Sciiences, 919, 2000, 318-320.

[16]. M. N. Rashed, Cadmium and lead levels in fish (Tilapia nilotica) tissues as biological indicator for lake water pollution, Environmental Monitoring and Assessment, 68, 2001, 75-89.

[17]. G. R. Scott, and K. A. Slowman, The effect of environmental pollutants on complex fish behaviour, integrating behavioural and physiological indicators of toxicity, Toxicology, 68, 2004, 369-392.

[18]. C. B. Schreck, and P. Brouha, Dissolved oxygen depletion in static bioassay system, Bulletin of Environmental Contamination and Toxicology, 14, 1975, 149-152.

[19]. K. K. Shukla, D. R. Tripathi, A. Shukla, and J. P. Shukla, Cadmium induced oxidative stress in Hepatocytes of snake-headed fish Channa punctatus (Bloch.) - an invitro study, International Journal of Pharma and Biosciences, 04, 2013, 721-729.

[20]. K. Shobha, A. Purnima, P. Harni, and K.Veeraiah, A study of biochemical changes in freshwater fish, Catla catla (Hamilton) exposed to the heavy metal toxicant cadmium chloride, Kathmandu University Journal of Science, Engineering and Technology, 01, 2007, 01-11.

[21]. O. M. Shuhaini, Y. Nadzifah, and A. K. Ahamad, Toxicity of copper and cadmium in freshwater fishes, World Academy of Science, Engineering and Technology, 41, 2010, 869-871.

[22]. N. N. Singh, V. K. Das, and A.K. Srivastav, Formothion and propoxur induced ionic imbalance and skeletal deformity in a catfish, Heteropneustes fossilis, Journal of Environmental Biology, 18, 1997, 357-363.

[23]. T. P. Srianga, M. P. Mahapatra, G. K. Panigrehy, B. C. Guru, and S.C. Patnaik, Studies of effect of cadmium toxicity on protein metabolism in brain and muscle tissue of a freshwater teleost, Channa punctatus, The Ecoscan, 04, 2010, $189-192$.

[24]. C. Szebedinszky, J. C. McGeer, D. G. McDonald, and C. M. Wood, Effects of chronic Cd exposure via the diet or water on internal organ-specific distribution and subsequent gill $\mathrm{Cd}$ uptake kinetics in juvenile rainbow trout (Oncorhynchus mykiss), Environmental Toxicology and Chemistry, 20, 2001, 597-607.

[25]. A. Wangsongsak, S. Utarnpongsa, M. Kruatrachue, M. Ponglikitmongkol, P. Pokethitiyook, and T. Sumranwanich, Alterations of organ histopathology and metallothionein mRNA expression in silver barb, Puntius gonionotus during subchronic cadmium exposure, Journal of Environmental Science (China), 19, 2007, 1341-1348.

[26]. D. A. Wright, and P.M. Welbourn, Cadmium in the aquatic environment, a review of ecological, physiological and toxicological effects on biota, Environmental Review, 02, 1994, 187-214. 